\title{
Trend of Implementation Foster Family Toddlers (FFT) Programin East Java Province at 2015-2019
}

\author{
Fadilatul Fahmiyah ${ }^{1}$, Lutfi Agus Salim² \\ ${ }^{1}$ Bachelor Student in Department Biostatistics and Demography, Faculty of Public Health, Universitas Airlangga, \\ Surabaya, Indonesia, ${ }^{2}$ Associate Professor in Department Biostatistics and Demography, Faculty of Public Health, \\ Universitas Airlangga, Surabaya, Indonesia
}

\begin{abstract}
Foster Family Toddlers (FFT) as an effort program to improve the knowledge and skills of parents fostering the development of children in a whole and optimal way. The result of 2018 Basic Health Research, East Java Province shows the percentage low birth weight is $6.5 \%$, underweight of toddler is $15 \%$, wasting of toddler is $8 \%$ and the coverage of exclusive breast milk is $40 \%$. East Java Health Profile 2018 showed of low birth weight is $3,7 \%$ and the coverage of exclusive breast is $76.83 \%$, underweight and wasting in toddler is not found numbers, but there is the weight of toddler in under red line is $0.77 \%$. Therefore, needs to know trend of the implementation of FFT in East Java. This study was quantitative descriptive research design with secondary data. The result showed the reporting of FFT group from 2015-2017 increased by $4.52 \%$ and decreased in 2017-2019 by $4.52 \%$ and has not reached the target of KKP $80 \%$. FFT member participation in $2015-2017$ increased by $3.78 \%$ and decreased in $2017-2019$ by $12.55 \%$. FFT family attendance at the 2015-2016 Meeting increased by $1.38 \%$ and decreased in $2016-2019$ by $1.24 \%$, and the family of members of FFT Child Card Users in 2015-2019 saw a continuous increase of 9.52\%. So the result of the trend of the implementation of activities is less maximal because there are still some obstacles to be considered.
\end{abstract}

Keywords: Foster Family Toddlers, child growth, chart reporting.

\section{Introduction}

Family development is an effort to realize quality families who live in a healthy environment through family development. Family development is the responsibility of all parties including NPFP as mandated in Law No. 52 of 2009 on Population Development and Family Development ${ }^{(1)}$. Family development policies are carried out through fostering resilience and family welfare ${ }^{(2)}$. One of them is implemented through improving the quality of children by providing access to information, education, counselling and services on

\section{Corresponding Author:}

\section{Lutfi Agus Salim}

Associate Professor in Department Biostatistics and Demography, Faculty of Public Health, Universitas Airlangga, Surabaya, Indonesia e-mail: lutfi.as@fkm.unair.ac.id care, parenting and child development to families with toddlers. Children are a valuable investment in the progress of a nation because the child is the future holder of the nation, therefore the child as a Human Resources (HR) must be built early on in order to create quality human resources for the future of the nation ${ }^{(3)}$.

Optimal growth and development is one of the rights of every child stipulated in Law No. 23 of 2002 on Child Protection article 26 items a and b. Under the Law, parents are obliged to nurture and develop children. This is the same as the rights of the child described in the Convention on the Rights of the Child. Based on this it is clear that optimal growth is the right of every child and should be obtained by the child. The realization of the goal is not separated from the role of parents as the child's first environment ${ }^{(4)}$.

The Ministry of National Development Planning noted that during 2018-2019 East Java Province is one of the provinces that is the priority area of stunting problem 
handlers. In 2018, East Java has 11 locus for stunting (including Jember Regency, Nganjuk Regency and Lamongan Regency), and in 2019 increased by 1 district, namely Kediri Regency ${ }^{(5)}$. Basic health research data in 2018 shows that there is a decrease in stunting rates compared to 2013, stunting rates in East Java are still at more than 30\%. 2018 Basic Health Research results, East Java Province the numbers are as follows: Underweight percentage of $6.5 \%$; underweight prevalence in toddlers by $15 \%$; the prevalence of wasting in toddlers is $8 \%$ and exclusive breast milk coverage is $40 \%{ }^{(6)}$. East Java Health Profile 2018 the percentage ofunderweightwas $3.7 \%$; and exclusive breast milk coverage of $76.83 \%$, for indicators of prevalence of underweight and wasting in toddlers there is no figure, however there is data that the figure of toddlers weight below the red line is $0.77 \%{ }^{(7)}$.

Recognizing the importance of fostering children's development early on, since 1984 the National Population and Family Planning Board (NPFP) established the Toddler Family Development Program (FFT), and since 1991 this program has developed into the FFT Movement. FFT implementation is an effort to improve the knowledge and skills of parents in fostering the development of children in a whole and optimal way, through the provision of physical, cognitive, socio, emotional and spiritual stimulation. By actively participating in FFT activities, parents are expected to have enough supplies to help their children live their toddler life properly, well and pleasantly ${ }^{(8)}$. Therefore, researchers are determined to study how the trend of implementing FFT activities in East Java Province in 2015-2019.

\section{Method}

This research was used quantitative research method with quantitative descriptive research designs. The data source is used secondary data. This study uses data sourced from the NPFPyearly report and also the policy for the implementation of the NPFP FFT Program.

\section{Results}

Implementation of FFT are activities that are carried out once a month. To perform its functions properly. The implementers of the FFT program in the field are trained cadres, while participants or members of the FFT group are parents and other family members who have toddlers (0-5 years) and preschool age (5-6 years) ${ }^{(9)}$. The formation of FFT Group is carried out as a family coaching platform to improve knowledge and skills in parenting and fostering children. The development of FFT group is carried out as an effort to improve the quality and quantity of the group through cooperation with related partners in both the government and private sectors. One form of development is the integrated FFTintegrated service post (POSYANDU)-PAUD (health, education) and the formation of FFT pilot groups in each sub-district ${ }^{(10)}$.

The recording and reporting in the Resilience Program for Children and Toddlers is carried out in a tiered way starting from the implementation of activities by FFT groups at the field level, villages, sub-districts, districts/cities, provinces and national. The recording and reporting of FFT activities is carried out by FFT cadres, including ${ }^{(11)}$ :

\section{FFT group registration card (K/0/FFT/10)}

2. FFT group record card $(\mathrm{C} / 1 / \mathrm{FFT} / 10)$

\section{FFT report card $(\mathrm{R} / 1 / \mathrm{FFT} / 10)$}

4. Activity notebooks include: attendance/registration books, records of activity implementation, work plans, ledgers, and participation notes of $\mathrm{kb}$ members.

Based on the chart above, shows that the trend from 2015-2017 increased by $4.52 \%$ which in 2015 the existing FFT group was 13,809 and which reported a total of 13,121 which means its achievement of $95.02 \%$, then in 2016 the existing FFT group numbered 15,052 and which reported a total of 14,549 which meant its achievement amounted to $96.66 \%$ and also in 2017 the existing FFT group numbered 14,912 and which reported a total of 14,843 which meant its achievement of $99.54 \%$. However, there was a decrease in 2017 2019 of 31, 32\% where in 2018 the existing FFT group amounted to 14,984 and which reported a total of 14,473 which meant its achievement amounted to $96.59 \%$, then in 2019 the existing FFT group amounted to 21,925 and which reported a total of 14,311 which means its branding of $65.27 \%$. This is because the target of the toddler's family who have to follow the FFT increases. 


\section{0}

20000

15000

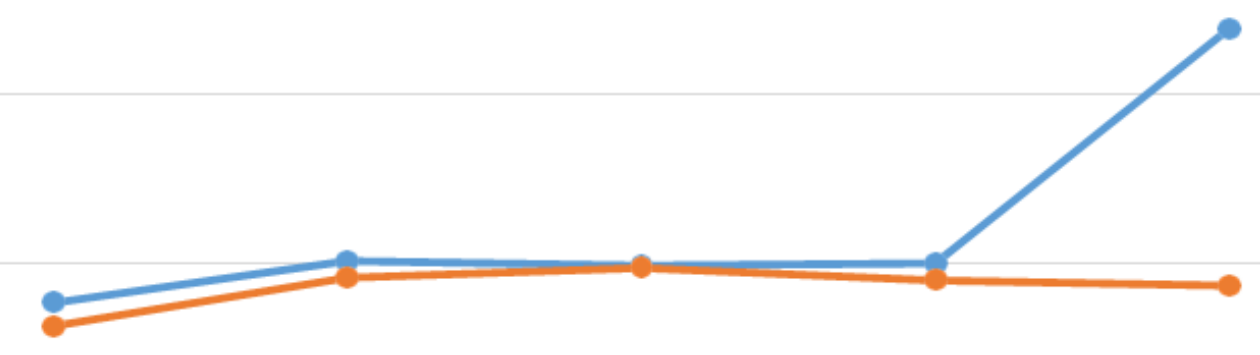

10000

5000

U

2015

2016

$201 \%$

2018

2019

$\longrightarrow \mathrm{FFI}^{\prime}$ Group (existıng) $\longrightarrow \mathrm{FHI}$ Group (was reported)

Figure 1 FFT Group Reporting Trends in East Java Year 2015-2019

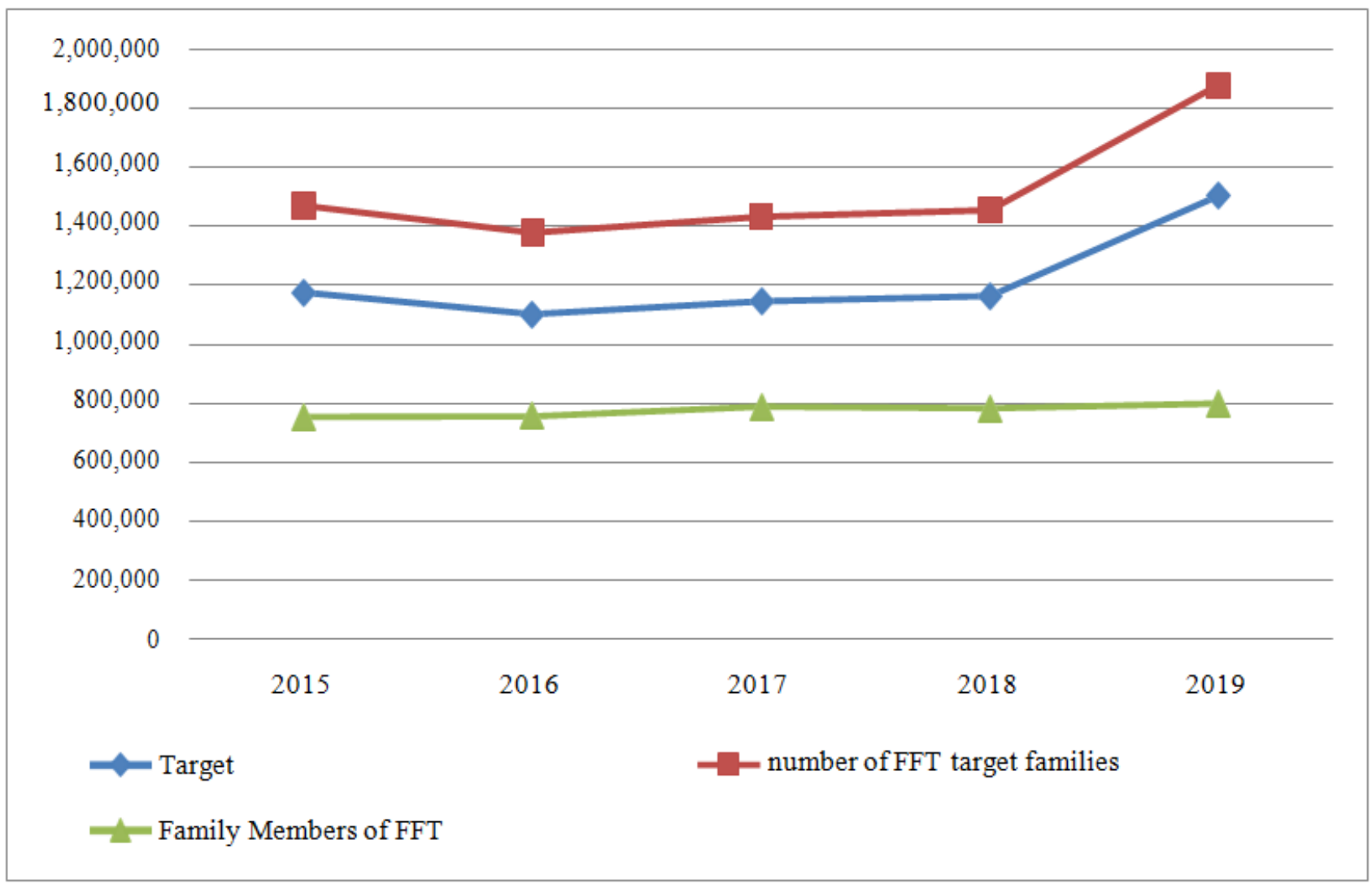

Figure 2 Trends of FFT Member Participation in East Java Year 2015-2019 
The results of the analysis showed that the trend from 2015-2017 increased by $3.78 \%$ where in 2015 the number of FFT target families was 1,470,022 and that FFT members total 754,998 which means the achievement of $51.36 \%$, then in 2016 the number of FFT target families is $1,378,877$ and who are members of FFT number 757,142 which means its achievement of $54.91 \%$ and also in 2017 the number of FFT target families is $1,432,658$ and which is a member of FFT number 789,918 which means its achievement of $55.14 \%$. If seen from the target of KKP that is $80 \%$ per year, then FFT membership has not reached the target of $2015(1,176,018), 2016(1,103,102)$, and 2017 $(1,146,126)$.

The trend of achievement decreased in 2017-2019 by $12.55 \%$ where in 2018 the number of FFT target families was $1,454,885$ and that became a member of FFT a total of 784,004 which means its achievement of $53.89 \%$, then in 2019 the number of FFT target families was $1,879,051$ and who became a member of FFT numbered 800,378 which means its achievement of $42.59 \%$. If seen from the target of KKP that is $80 \%$ per year, then FFT membership has not reached the target of $2018(1,163,908)$, and in $2019(1,503,241)$. The surge in family participation trends following FFT can be due to the declining number of coaches in the field, people tend to have less interest in finding knowledge and parenting skills through FFT and start relying on gadgets to find knowledge.

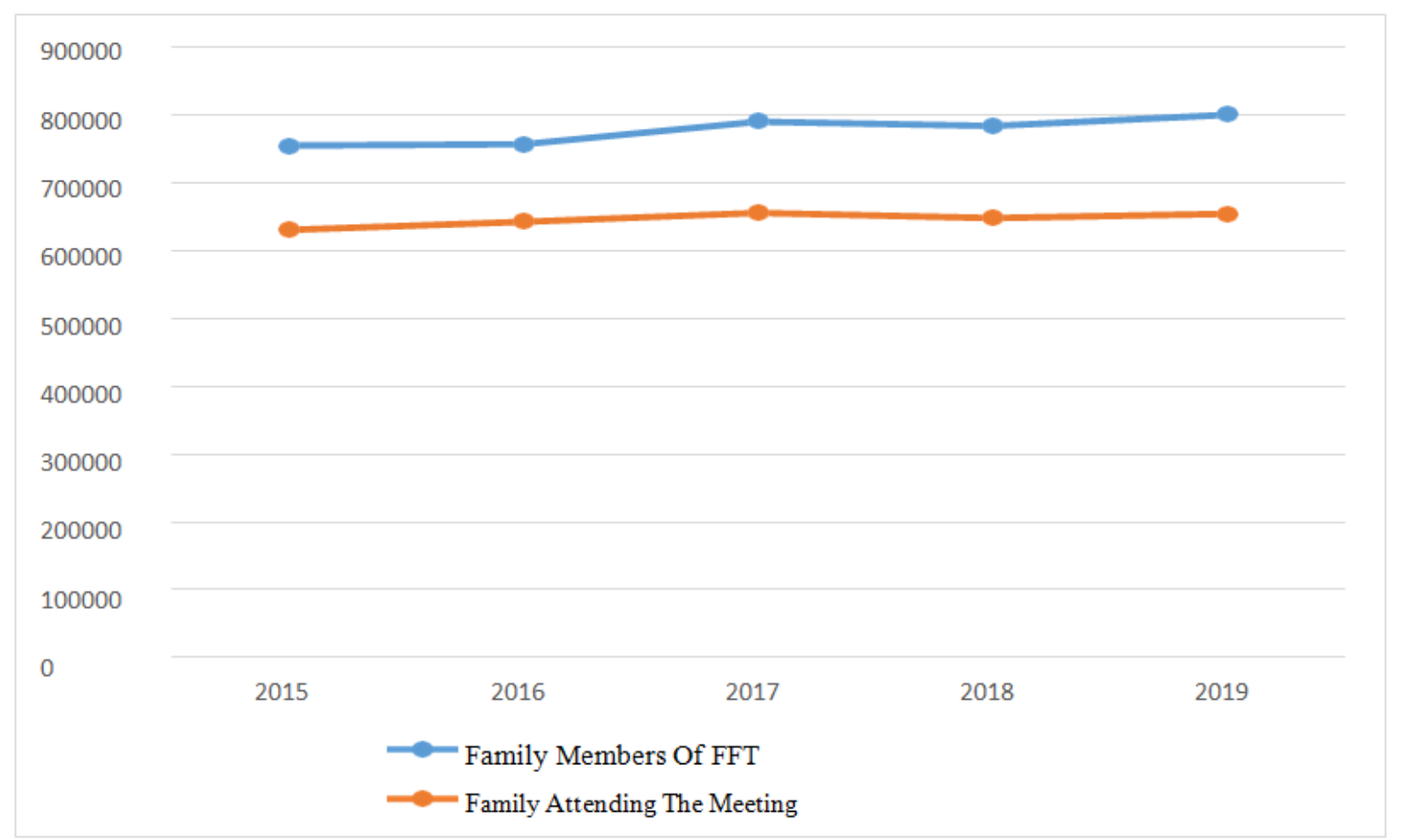

Figure 3 Trends of FFT Family Attendance in East Java Meeting 2015-2019

Based on the chart, showing that the trend from 2015-2016 increased by $1.38 \%$ where in 2015 families attended the meeting as many as 630,963 of the families who were members of the FFT as much as 754,998 which meant the achievement of $83.57 \%$, then in 2016 the family attended the meeting as many as 642,762 of the families who became members of FFT as much as 757,142 which means its achievement amounted to $84.89 \%$. However, there was a decrease in 2016-2019 of $1.24 \%$ where in 2017 the family attended the meeting as many as 655,862 of the families who became members of FFT as much as 789,918 which meant the achievement was $83.03 \%$, in 2018 the family attended the meeting of 648,325 of the families who became members of FFT as many as 784,004 which means the achievement of $82.69 \%$, then in 2019 the family attended the meeting as many as 654,633 of the families who became members of FFT as much as 800,378 which means the achievement of $81.79 \%$. 


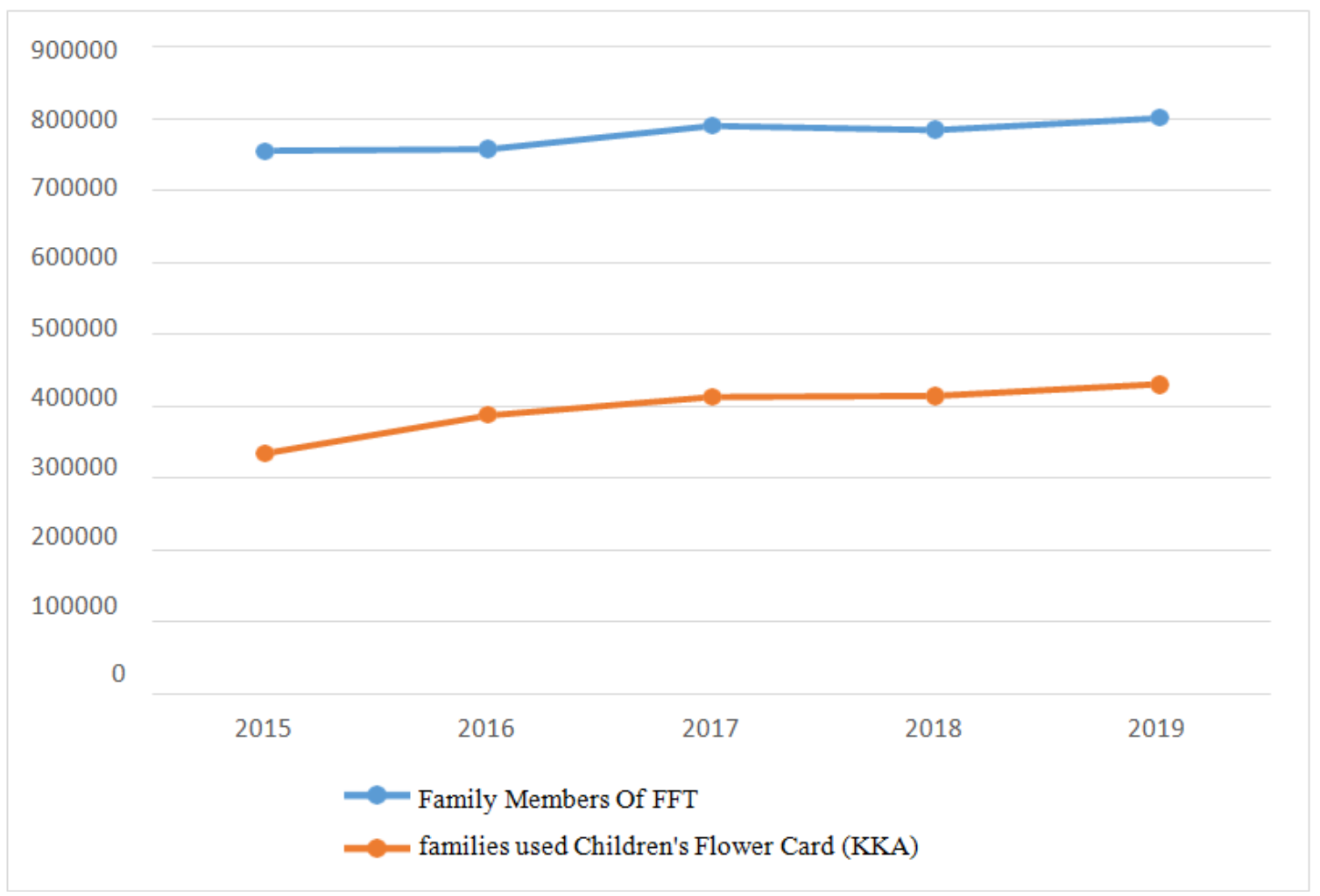

Figure 4 Trends of Family Members of FFT Using KKA in East Java in 2015-2019

Based on the chart, showing that the trend from 2015-2019 increased continuously by $9.52 \%$ where in 2015 FFT member families used Children's Flower Card (KKA) by 334,341 of the families who became FFT members as much as 754,998 which means its achievement of $44.28 \%$, then in 2016 the family of FFT members used KKA as much as 387,288 from families who became members of FFT as much as 757,142 which means its achievement of $51.15 \%$, in 2017 the family of FFT members used KKA as much as 413,041 from families who became members of FFT as much as 789,918 which means its achievement of $52.29 \%$, in 2018, the family of FFT members used KKA as much as 414,207 from families who became members of FFT as much as 784,004 which means its achievement of $52.83 \%$, and in 2019 the family of FFT members used KKA as much as 430,575 from families who became members of FFT as much as 800,378 which means its achievement of $53.80 \%$.

\section{Discussion}

The government has made various efforts to improve the quality of human resources, among others through the Integrative Holistic Early Childhood Development Program. This program is strengthened by Presidential
Regulation No. 60/2013 on Integrative Holistic Early Childhood Development. With the implementation of holistic integrative early childhood development, it is hoped that the essential needs of early childhood in its entirety including health and nutrition, stimulation of education, moral-emotional coaching, and parenting can be $\operatorname{met}^{(12)}$.

The National Family Planning and Population Board (NPFP) also plays a role in the implementation of integrative holistic early childhood development through the Toddler Family Development (FFT) activity group. Integrative holistic early childhood development is carried out in FFT, early childhood education program Post, and integrated service post-groups. The FFT group improves the knowledge of parents and families who have toddlers regarding parenting; early childhood education program Post provides educational services to early childhood; while integrated service post provides health services for early childhood. Some of the obstacles found in the implementation of FFT, include ${ }^{(13)}$ :

1. Limited number of FFT cadres, due to difficulty regeneration of workers and lack of operational support, among others: fee, etc. 
2. Limited number of Family Planning Counselors (PKB) handling in the field.

3. FFT cadres who are concurrent as integrated service post cadres so that the implementation of FFT activities does not optimal.

4. Number of cadres, because between the number of cadres and the number of participants is not balanced

5. Inefficient time utilization is also a factor in inhibiting FFT program.

The pattern of child care is also inseparable from the culture of child play. In developmental psychology literature, children aged 0-6 are "good impersonators" and "tenacious learners", but not a "good listener"(14). Children of this age will be easier to learn and understand by doing activities, not by being told or just words. Therefore, early childhood requires play activity to stimulate nerve development. According to Freud and Erikson playing for a child is very useful as a form of self-adjustment, helping the child master the anxieties and conflicts it faces(3). The game is believed to be able to relieve tension so as to help the child in solving problems and conflicts faced in his life. To realize the above, it is necessary to create a meaningful learning environment for early childhood, among others through a variety of meaningful games that are able to provide comfort for the child in learning and the right stimulation will be realized(15).

\section{Conclusion}

Theimplementation of theFamily ResilienceProgram of Toddlers and Children is outlined in the Operational Guide to the Implementation of The Resilience Program of Toddlers and Children namely the development of operational policies and strategies, formation and development of FFT groups, the development and provision of FFT Kit facilities, socialization, coaching, monitoring and evaluation of coaching and recording and reporting. FFT Group Reporting Chart shows the trend from 2015-2017 increased by 4.52\% but decreased in $2017-2019$ by $31.32 \%$. However, if you look at the target of KKP $80 \%$, then the results have not reached the target. FFT Member Participation Chart shows that the trend from 2015-2017 increased by 3.78\% but decreased in $2017-2019$ by $12.55 \%$. The FFT Family Attendance graph in the Meeting shows that the trend from 20152016 increased by $1.38 \%$ but decreased in 2016-2019 by $1.24 \%$, and the KKA User FFT Member Family chart shows that the trend from 2015-2019 increased continuously by $9.52 \%$. Although the result of the trend has decreased or increased, in the implementation of activities there are still some obstacles to be considered.

\section{Recommendation:}

1. Improving institutional strengthening with integrative systems and efforts to prepare aspects of legitimacy such as decision letter (SK), implementation guidelines, technical instructions and so on.

2. Improving commitment, coordination and cooperation with relevant partners, stakeholders and with communities/associations/organizations related to FFT group organizing

Conflict of Interest: The authors have no conflict of interest with the material presented in this paper.

Source of Funding: None.

Ethical Clearance: None. This research was conducted without treating informants

\section{Reference}

1. The Coordinating Ministry for Human Development and Culture of the Republic of Indonesia. Undangundang no 52Tahun 2009 tentang Perkembangan Kependudukan dan Pembangunan Keluarga. 2009;

2. National Population and Family Planning Board Indonesia. Keluarga Berencana dan Kesehatan Reproduksi. Jakarta: National Population and Family Planning Board; 2005.

3. Santrock JW. Adolescence [Internet]. McGrawHill; 1998. (Brown and Benchmark Series). Available from: https://books.google.co.id/ books?id=KZIEAQAAIAAJ

4. Nutbrown C, Clough P. Pendidikan anak usia dini: Sejarah, filosofi, dan pengalaman. Yogyakarta: Pustaka Pelajar. 2015;

5. Minister of National Planning Development. Pedoman Pelaksanaan Intervensi Penurunan Stunting Terintegrasi di Kabupaten/Kota. Jakarta: Minister of National Planning Development; 2018.

6. Ministy of Health. Riset Kesehatan Dasar 2018. Jakarta: Ministry of Health; 2019.

7. Ministry of Health in East Java. Health Profile in East Java 2018. 2019.

8. National Population And Family Planning Board East Java. Hasil Analisis dan Evaluasi Program 
KKBPK-Maret 2015. Surabaya: National Population And Family Planning Board East Java; 2015.

9. National Population and Family Planning Board Indonesia. Kesehatan Reproduksi. Jakarta: National Population and Family Planning Board; 2008.

10. National Population and Family Planning Board Indonesia. Kumpulan Istilah Bidang Keluarga Berencana. Jakarta: National Population and Family Planning Board; 1984.

11. National Population and Family Planning Board Indonesia. Pengasuhan dan Pembinaan Tumbuh Kembang Anak. Jakarta: National Population and Family Planning Board; 2009.
12. National Population and Family Planning Board Indonesia. Buku Pegangan Kader Bina Keluarga Balita. Jakarta: National Population and Family Planning Board; 2007.

13. Mardiyono. Model Pengelolaan Bina Keluarga Balita (BKB) Di Propinsi Jawa Timur. Cakrawala: Jurnal Litbang Kebijakan. 2012;6(2):184-94.

14. Susanto A. Perkembangan Anak Usia Dini: pengantar dalam berbagai aspeknya [Internet]. Yogyakarta:Kencana; 2011. Available from: https:// books.google.co.id/books?id=qvOAAQAACAAJ

15. Santrock JW. Masa perkembangan anak. Jakarta: Salemba Humanika. 2011; 